\title{
Humanização do Parto: Relato de Experiência com Alunos do Curso de Medicina.
}

\author{
Almeida, Janie Maria de; Sampaio Neto, Luiz Ferraz de \\ Pontificia Universidade Católica de São Paulo — janie@pucsp.br
}

Introdução: Há algumas décadas enfrentamos no Brasil um paradoxo no nascimento. a intensa medicalização influenciou de forma determinante o modo de nascer, reduzindo este grande acontecimento fisiológico da vida familiar e social a uma intervenção médicacirúrgica. ao mesmo tempo, os índices de mortalidade materna e infantil persistem muito altos e as causas de morte são em grande parte evitáveis por ação dos serviços de saúde. Mudanças estão ocorrendo, sobretudo no sistema de saúde, no entanto, as instituições formadoras continuam preparando profissionais embasados em modelos que não valorizam a assistência humanizada no parto, atendimento que respeita os aspectos fisiológicos, sociais e culturais do parto. por meio de proposta do Pró-Saúde e PET-Saúde atividades educativas e assistenciais são desenvolvidas por alunos de medicina, respaldados no referencial de humanização da assistência ao parto e atenção hospitalar, preconizados pelo Ministério da Saúde e Organização Mundial de Saúde. Objetivos: Esta prática acadêmica pretende aperfeiçoar habilidades dos alunos nos cuidados a gestantes, destacando os aspectos da humanização da assistência ao parto, para que estes vivenciem e reflitam sobre a experiência deste aprendizado. Métodos: As atividades foram organizadas em três unidades de saúde da cidade de Sorocaba, envolvendo 2 alunos em cada local, desde outubro de 2012 junto ao programa do Pré-Natal. Os estudantes abordaram às gestantes na consulta do pré-natal, a partir de 24 semanas de gestação e ofereceram a elaboração do Plano de Parto, por meio de roteiro com informações relacionadas ao parto, como: escolha do acompanhante e orientações direcionadas ao início do trabalho de parto, medidas de conforto, técnicas de respiração, relaxamento e suporte emocional à mulher. Resultados: em 18 meses de execução do projeto, tivemos a participação de 12 alunos. Foram realizadas várias estratégias ativas para capacitá-los, considerando a interação de aspectos biológicos, sociais e afetivos do parto bem como seu impacto na vida da mulher e da família. para subsidiar a abordagem junto às gestantes, uma oficina de comunicação, constou com práticas de simulação e uma vivência sobre estar grávida utilizando avental grávido. Discussões sobre a temática incluíram as recomendações da OMS para o parto seguro, as evidências científicas pertinentes, bem como a política para a área, houve também acompanhamento de projetos voltados para gestantes desenvolvidos no município e em maternidade escola. Os alunos participaram na elaboração do roteiro do plano de parto. Conclusões: o projeto vem demonstrando relevância para os alunos na prática da humanização, com habilidades de escuta, acolhimento e compreensão das necessidades de cuidado da mulher durante os períodos gestacional e da parturição, destacando o respeito ao processo fisiológico do nascimento.

Almeida, Janie Maria de; Sampaio Neto, Luiz Ferraz de. Humanização do Parto: Relato de Experiência com Alunos do Curso de Medicina.. In: Anais do Congresso Internacional de Humanidades \& Humanização em Saúde [= Blucher Medical Proceedings, num.2, vol.1]. São Paulo: Editora Blucher, 2014. ISSN 2357-7282 DOI 10.5151/medpro-cihhs-10317 